University of Nebraska - Lincoln

DigitalCommons@University of Nebraska - Lincoln

2013

Development of restoration trajectory metrics in reforested bottomland hardwood forests applying a rapid assessment approach

Jacob F. Berkowitz

US Army Corps of Engineers, Jacob.F.Berkowitz@usace.army.miljurisdiction

Follow this and additional works at: https://digitalcommons.unl.edu/usarmyresearch

Berkowitz, Jacob F., "Development of restoration trajectory metrics in reforested bottomland hardwood forests applying a rapid assessment approach" (2013). US Army Research. 182.

https://digitalcommons.unl.edu/usarmyresearch/182

This Article is brought to you for free and open access by the U.S. Department of Defense at DigitalCommons@University of Nebraska - Lincoln. It has been accepted for inclusion in US Army Research by an authorized administrator of DigitalCommons@University of Nebraska - Lincoln. 


\title{
Development of restoration trajectory metrics in reforested bottomland hardwood forests applying a rapid assessment approach
}

\author{
Jacob F. Berkowitz ${ }^{\mathrm{a}, \mathrm{b}, *}$ \\ a Wetlands and Coastal Ecology Branch, US Army Corps of Engineers, Engineer Research and Development Center, Vicksburg, MS, United States \\ ${ }^{\mathrm{b}}$ Wetland and Aquatic Biogeochemistry Laboratory, Louisiana State University, Baton Rouge, LA, United States
}

\section{A R T I C L E I N F O}

\section{Article history:}

Received 30 July 2012

Received in revised form 24 June 2013

Accepted 27 June 2013

\section{Keywords:}

Restoration trajectory

Wetland

Rapid assessment

Hydrogeomorphic (HGM) approach

Bottomland hardwood forest

Mississippi valley

\begin{abstract}
A B S T R A C T
Large scale wetland restoration and reforestation efforts continue to expand throughout the Lower Mississippi Valley. Monitoring of restoration performance and the development of restoration trajectories pose challenges to resource managers and remain problematic due to (1) temporal patterns in forest succession, (2) budget constraints and short project monitoring timeframes, (3) disparity in the extent of pre-restoration hydrologic and landscape manipulations, and (4) lack of coherent restoration performance standards. The current work establishes a framework for identifying restoration trajectory metrics within project-relevant timescales. The study examined 17 variables commonly applied in rapid assessments. Four variables yielded positive restoration trajectories within a few years to 20 years. These include shrub-sapling density, ground vegetation cover, and development of organic and A soil horizons. Remaining variables including flood frequency and tree density provide limited useful information within critical early years following reforestation due to the time required for measurable changes to occur. As a result, assessment components are classified into three categories of rapid response, response, and stable variables. Restoring entities should maximize stable variables (e.g., afforestation species composition) during project implementation through site selection and planting techniques; while development of restoration milestones should focus on rapid response variables. Data collected at mature bottomland hardwood control sites displays the non-linearity of trajectory curves over decadal time scales.
\end{abstract}

Published by Elsevier Ltd.

\section{Introduction}

A variety of factors including settlement expansion, agriculture and forestry, and flood control decreased wetland acreages within the Lower Mississippi Valley (LMV) by $74 \%$ by 1982 ; with only 2.8 of an original 10 million ha remaining today (Gardiner and Oliver, 2005; The Nature Conservancy, 1992; King et al., 2006). LMV wetland loss rates exceed all other portions of the United States, creating an area of concern in terms of both wetland acreage and wetland functional losses (Hefner and Brown, 1995). During the 1970s and 1980s public and private organizations recognized the negative impacts of wetland functional degradation and began promoting wetland restoration designed to repair damaged and degraded ecosystems within the region (U.S. Congress., 1985; Haynes et al., 1995; Hobbs and Cramer, 2008). In response, an estimated 275,000 ha of bottomland hardwood forest LMV has undergone reforestation, including over 20,000 acres under the

\footnotetext{
* Corresponding author at: Wetlands and Coastal Ecology Branch, US Army Corps of Engineers, Engineer Research and Development Center, 3909 Halls Ferry Rd, Vicksburg, MS 39180, United States. Tel.: +1 601634 5218; fax: +1 6015293205.

E-mail address: Jacob.F.Berkowitz@usace.army.mil
}

jurisdiction of the U.S. Army Corps of Engineers (U.S. Army Corps of Engineers, 1989; Allen et al., 2000; King et al., 2006; King and Keeland, 1999). Recently, the science and practice of ecological restoration has evolved to focus on maximizing ecological functionality within current biotic and abiotic constraints (Harris et al., 2006; Jackson and Hobbs, 2009).

Despite increases in wetland acreage resulting from large-scale restoration projects, no consensus exists regarding performance standards or early successional trajectory curves in forested systems (Thom, 1997; Ruiz-Jaen and Aide, 2005; Hughes et al., 2005). Recent work suggests measures of performance focus on vegetation composition, ecosystem processes, species diversity, and structural benchmarks (Gardiner et al., 2004; Wilkins et al., 2003; Hamel, 2003; Allen, 1997). However, calibration of appropriate methods for determining restoration performance continues to lack clarity, specifically within the first few years following restoration (Steyer et al., 2003).

The time frames associated with forested wetland restoration complicate the establishment of performance standards (Hobbs and Harris, 2001; Kusler, 1986). Bottomland hardwood ecosystems require multiple decades to reach maturity, while regulatory agencies typically require less than a decade (commonly $<5$ years) of permit applicant sponsored post-project monitoring to determine 
Table 1

Summary of site characteristics: location, area reforested, number of independent forests sampled, age, and condition.

\begin{tabular}{|c|c|c|c|c|}
\hline County, State & Area replanted (ha) & Forests sampled & Age (years) & Condition \\
\hline Bolivar, MS & 344 & 5 & 1 & Restored \\
\hline Ouachita, LA & 1212 & 5 & 1 & Restored \\
\hline Bolivar, MS & 1011 & 5 & $6-7$ & Restored \\
\hline Quitman, MS & 217 & 5 & $6-7$ & Restored \\
\hline Washington, MS & 140 & 5 & $6-7$ & Restored \\
\hline Washington, MS & 210 & 5 & $11-12$ & Restored \\
\hline Washington, MS & 186 & 5 & $11-12$ & Restored \\
\hline Yazoo, MS & 3499 & 10 & 20 & Restored \\
\hline Yazoo, MS & - & 5 & $>80$ & Control \\
\hline Sharkey, MS & - & 21 & $>80$ & Control \\
\hline Total & 6819 & 71 & & \\
\hline
\end{tabular}

restoration performance (Clewell and Lea, 1990; Landin and Webb, 1986). The temporal variability associated with ecosystem restoration remains problematic as few studies establish a restoration chronosequence exhibiting restored forest dynamics and functionality over time (Spencer et al., 2001).

In addition to the problems posed by forest successional changes, restoration trajectory is also influenced by the extent of site manipulation associated with restoring activities. For example many sites undergo plantings of ecologically desirable species (Stanturf and Gardiner, 2000; Humphrey et al., 2004), while other areas are subject to natural regeneration following clearcutting or abandonment of previously farmed fields (Spencer et al., 2001; Battaglia et al., 2002). The amount of on-site preparation and changes to site hydrology and topography influence restoration outcomes, however the lack of an equal starting point for restoration complicates establishing performance standards. Often, responsible parties and agency staff are limited by budgetary and time constraints for post-restoration monitoring, compliance activities, and remediation of low quality restoration efforts.

The Hydrogeomorphic (HGM) Approach and other rapid assessment techniques examine wetland components to assess ecosystem function or condition (Brinson, 1993; Brinson et al., 1994; Stein et al., 2009). HGM has been widely applied because it specifically focuses on requirements of the Clean Water Act and has been utilized to monitor many wetland ecosystem types (Brinson and Rheinhardt, 1996; Klimas et al., 2004; Humphrey et al., 2004). HGM collects data on a number of structural ecosystem components and applies multimetric equations to develop an index of wetland function or condition; providing a practical basis for evaluating wetland areas.

Kentula et al. (1992) and Zedler (1996) identified the need for establishment of performance standards or criteria for ecological restoration and mitigation projects. Further, Smith and Klimas (2002) and Klimas et al. (2004) examined expected recovery patterns within selected wetland assessment variables. The current work builds upon the available literature by (1) identifying rapid assessment variables that respond quickly following restoration, (2) developing statistically significant early stage restoration performance standards for reforested wetlands, and (3) providing examples of potential applications for restoration trajectories.

\section{Methods}

\subsection{Study area}

Study area selection was based on criteria including (1) restoration project implemented within project relevant timescales $(<20$ years), (2) construction of a restoration chronosequence, (3) previous land use of $100 \%$ agricultural with no hydrologic restoration occurring onsite, and (4) located proximal to the region addressed by the assessment method developed for use in the study area. In order to minimize potentially confounding effects due to topographic location and hydrology, all selected study areas classified as riverine backwater wetlands as defined in Smith and Klimas (2002). Forty-five reforested sites ranging from 1 to 20 years post planting were examined during the study. The study area included sample plots located within the Yazoo Basin in Mississippi with one site located nearby in Louisiana (Table 1; Fig. 1).

Study area age was determined by the dates of reforestation activities and historical documentation. Restoration activities utilized seedling planting and did not include hydrologic modification such as alterations to existing water control structures (e.g., ditches or levees). Planted species included a mixture of water oak (Quercus nigra), willow oak (Quercus phellos), Nuttall oak (Quercus texana), Shumard oak (Quercus shumardii), green ash (Fraxinus pennsylvanica), pecan (Carya illinoensis), and bald cypress (Taxodium distichum).

Twenty-six mature control sampling plots were also examined within the Delta National Forest. Control sites exhibited second growth forests $>80$ years old and represent the least disturbed forested wetlands in the region. Sample areas receive hydrologic inputs from precipitation and backwater flooding and occur within meander belts 2 and 3 of the Mississippi river floodplain (Saucier, 1994). Soils throughout the study area were characterized by Sharkey, Dowling, Perry, and Alligator poorly drained clay soils with small inclusions of somewhat poorly drained Commerce silty clay loam. All observed soil series phases were between 0 and 2 percent slope (Soil Survey Staff, 2011).

\subsection{Selection of variables and data collection}

The selection of variables was based upon the assessment protocols outlined in Smith and Klimas (2002) who developed an HGM guidebook specifically calibrated within the study area. The potential application of HGM variables as measures of restoration trajectory provides several advantages including (1) data collection protocols are rapid (Berkowitz et al., 2010) and (2) utilize sampling measurements and protocols that resource professionals are familiar with (i.e., determination of tree diameter at breast height; Mack, 2007; Stander and Ehrenfeld, 2009). Further, the protocols provided in Smith and Klimas (2002) are currently applied as part of ongoing monitoring efforts, providing an available source of data with the potential to produce science-based, applicable tools for developing restoration trajectories and performance standards.

Smith and Klimas (2002) identify seventeen variables commonly applied in wetland assessments. Variables included off-site and on-site measurements. Off-site variables evaluated flood regime, restoration site configuration, and the characteristics of adjacent properties. On-site variables included examination of soil characteristics, vegetative composition and vigor, and the degree of site disturbance (Table 2). Smith and Klimas (2002) provide detailed 


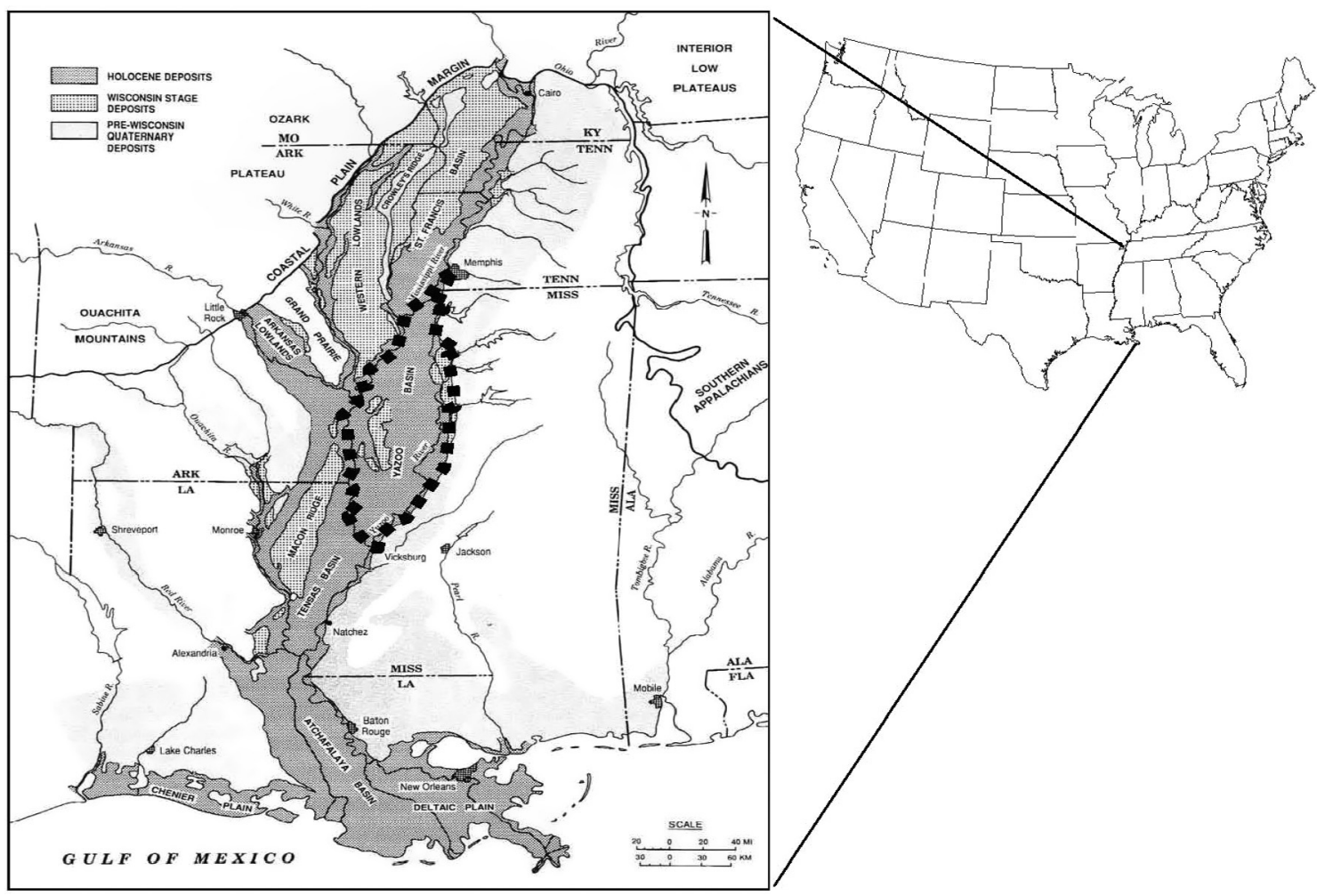

Fig. 1. Study area. The Yazoo basin is highlighted. (Saucier, 1994).

Table 2

Summary of rapid assessment variables, description, and sampling technique. Response variables $\left({ }^{\dagger}\right)$ and rapid response variables $\left(^{\ddagger}\right)$ are identified.

\begin{tabular}{|c|c|c|}
\hline Rapid assessment variable & Description & Sampling technique \\
\hline 1. Core Area & $\begin{array}{l}\text { Portion of wetland lying within } 100 \mathrm{~m} \\
\text { buffer }\end{array}$ & Measured from aerial photo/GIS layer \\
\hline 2. Habitat connections & $\begin{array}{l}\text { Proportion of the wetland perimeter } \\
\text { connected to suitable habitat }\end{array}$ & Measured from aerial photo/GIS layer \\
\hline 3. Wetland tract & $\begin{array}{l}\text { Contiguous wetland area adjacent to the } \\
\text { wetland }\end{array}$ & Measured from aerial photo/GIS layer \\
\hline 4. Flood frequency & $\begin{array}{l}\text { Frequency of overbank or backwater } \\
\text { flooding }\end{array}$ & $\begin{array}{l}\text { Measured from flood frequency } \\
\text { map/stream gauge data }\end{array}$ \\
\hline 5. Cation exchange capacity & $\begin{array}{l}\text { Cation exchange capacity change due to } \\
\text { soil disturbance }\end{array}$ & Estimated based on soil type \\
\hline 6. Soil integrity & $\begin{array}{l}\text { Proportion of the wetland exhibiting } \\
\text { altered soils }\end{array}$ & $\begin{array}{l}\text { Estimated based on amount of soil } \\
\text { disturbance visible }\end{array}$ \\
\hline 7. Micro-depressional ponding & $\begin{array}{l}\text { Percentage of small topographic } \\
\text { depressions and vernal pool features }\end{array}$ & $\begin{array}{l}\text { Estimated based on percent of depressions } \\
\text { within sample area }\end{array}$ \\
\hline 8. Tree basal area ${ }^{\dagger}$ & $\begin{array}{l}\text { Basal area per hectare; proportional to tree } \\
\text { biomass }\end{array}$ & $\begin{array}{l}\text { Measured DBH of all trees }>7.6 \mathrm{~cm} \text { in } \\
\text { diameter within circular } 0.04 \text { ha plot }\end{array}$ \\
\hline 9. Tree density ${ }^{\dagger}$ & Number of trees per hectare & $\begin{array}{l}\text { Count of all trees }>7.6 \mathrm{~cm} \text { in diameter } \\
\text { within circular } 0.04 \text { ha plot }\end{array}$ \\
\hline 10. Snag density ${ }^{\dagger}$ & Density of standing dead woody stems & $\begin{array}{l}\text { Count of all snags }>7.6 \mathrm{~cm} \text { in diameter } \\
\text { within circular } 0.04 \text { ha plot }\end{array}$ \\
\hline 11. Tree composition & Species composition of the tallest stratum & $\begin{array}{l}\text { Percent concurrence with measured tree } \\
\text { quality index within the uppermost } \\
\text { stratum }\end{array}$ \\
\hline 12. Woody debris biomass ${ }^{\dagger}$ & $\begin{array}{l}\text { Volume of woody debris biomass per } \\
\text { hectare }\end{array}$ & $\begin{array}{l}\text { Count of nonliving stems along a } 3.7 \mathrm{~m} \\
\text { transect }\end{array}$ \\
\hline 13. Log biomass ${ }^{\dagger}$ & Volume of log biomass per hectare & Count of logs along a $15 \mathrm{~m}$ transect \\
\hline 14. Shrub-sapling density $\ddagger$ & Density of saplings and shrubs per hectare & $\begin{array}{l}\text { Count of all woody stems within two } \\
0.004 \text { ha plots }\end{array}$ \\
\hline 15. Ground vegetation cover ${ }^{\ddagger}$ & $\begin{array}{l}\text { Percent cover of herbaceous and woody } \\
\text { vegetation }\end{array}$ & $\begin{array}{l}\text { Visually estimated percentage of ground } \\
\text { covered with herbaceous and woody } \\
\text { vegetation within four } 1 \mathrm{~m}^{2} \text { plots }\end{array}$ \\
\hline 16. O horizon biomass ${ }^{\ddagger}$ & Mass of organic matter in the $\mathrm{O}$ horizon & Measured O horizon thickness \\
\hline 17. A horizon biomass $\ddagger$ & Mass of organic matter in the A horizon & Measured A horizon thickness \\
\hline
\end{tabular}


sampling instructions for each of the variables examined. Data collection occurred during the spring and early summer of 2011.

Additionally, measurements of onsite hydrology, river stage, precipitation, and soil carbon were collected. Within each study area, triplicate soil cores $(10 \mathrm{~cm}$ deep) were homogenized and maintained at $4{ }^{\circ} \mathrm{C}$ until total organic carbon was measured as loss on ignition of dried ground samples at $550^{\circ} \mathrm{C}$ in a muffle furnace for $4 \mathrm{~h}$ (Sparks, 1996). Climate data reports daily precipitation values collected at the Vicksburg/Tallulah Primary Local Climatological Data Site (National Weather Service., 2012). River stage was determined within the center of the study area utilizing the Big Sunflower River gauge located at Holly Bluff, MS (U.S. Army Corps of Engineers, 2012). Direct monitoring of near-surface hydrology utilized slotted groundwater wells installed $50 \mathrm{~cm}$ below the soil surface. One groundwater well was located at the center of each study area, establishing the hydrology within the immediate area represented by the HGM assessment. Water table level recordings were taken twice daily using Insitu Level TROLL 500 dataloggers (Ft. Collins, CO). Well construction, installation, and data analysis followed U.S. Army Corps of Engineers. (2005). The National Research Council. (1995) defined high water tables as occurring within $30 \mathrm{~cm}$ of the surface, ensuring saturation or inundation within the majority of the root zone. This represents the area considered critical for wetland functioning (Chorover et al., 2007). As a result, water table data are expressed as the number of high-water table days (i.e. the incidence of water tables $>30 \mathrm{~cm}$ ) occurring during the monitoring period (Berkowitz and Sallee, 2011).

\subsection{Data analysis}

Forest ages were combined into two year increments because planting periods vary between November and June. For example, forests restored 11 and 12 years ago were grouped together. One vegetation sample plot and associated sampling transects were located within each forest as outlined in Smith and Klimas (2002). Each sampled forest was treated as an independent sample; results report average values based upon forest age. Pearson Product Moment Correlations compare variables with restoration forest age. Where strong correlations (critical value $r>0.418, p<0.01$, $n=45$ ) were observed within the first 20 years following restoration, significance between forest ages was determined by applying one-way ANOVA following testing for normality (Shapiro-Wilk test) and homogeneity of variance (Levene Statistic). The nonparametric Krustal-Wallis test was applied in cases where data was not normally distributed. Multiple comparisons analysis was conducted using Tukey HSD and LSD tests. Significance levels were evaluated at $\alpha=0.05$ (SPSS, 2011 SPSS IBM, Inc. Version 20).

\section{Results and discussion}

Shrub-sapling density, ground vegetation cover, $\mathrm{O}$ horizon and A horizon thickness represent the only 4 of 17 variables measured within the assessment protocol that display significant correlations with restoration forest age (Table 3 ). The fact that several variables correlated with stand age shortly after restoration suggests a potential utility in evaluating linkages between variable outcomes and restoration site performance. As a result, these four variables were selected for additional analysis as potential indicators of restoration trajectory and performance within the first years following reforestation. Shrub-sapling density and ground vegetation cover were normally distributed $(F(3,45)=32.6$ and $F(3,45)=12.55$ respectively) while $O$ horizon and $A$ horizon thickness were not normally distributed $(F(3,45)=76.4$ and $F(3,45)=32.6$ respectively). In all cases when comparing variable outcomes to forest age, significant differences $(p<0.01)$ were observed at the $\alpha=0.05$ level.
Table 3

Pearson Correlation outputs comparing rapid assessment variables to restoration forest age within $12^{\mathrm{a}}-20$ years. With $n=45, r>0.418$ is significant to $p=0.01^{\ddagger}$

\begin{tabular}{llll}
\hline Variable & $r$ & Variable & $r$ \\
\hline 1. Core area & 0.30 & 10. Snag density & 0.01 \\
2. Habitat connections & 0.22 & 11. Tree composition & 0.07 \\
3. Wetland tract & 0.24 & 12. Woody debris biomass & 0.30 \\
4. Flood frequency & 0.32 & 13. Log biomass & 0.24 \\
5. Cation exchange capacity & 0.01 & 14. Shrub-sapling density & 0.59 \\
6. Soil integrity & 0.01 & 15. Ground vegetation cover & 0.64 \\
7. Micro-depressional ponding & 0.13 & 16. O horizon thickness & 0.85 \\
8. Tree basal area & 0.03 & 17.A horizon thickness & 0.89 \\
9. Tree density & 0.07 & & \\
\hline
\end{tabular}

All four variable outputs increase during years 0-12 following planting (Fig. 2). Examining the entire restoration chronosequence, the soil $\mathrm{A}$ and $\mathrm{O}$ horizon variables show a distinctly different pattern than shrub-sapling density and ground vegetation variables. The depth of both $\mathrm{O}$ and $\mathrm{A}$ horizon variables increases throughout the restoration chronosequence. Because the figure displays both soil horizon depth and forest age, the slope between depth and age represents the rate of soil horizon change. The two soil horizon variables display a decrease in the rate of soil horizonation as restoration forests develop toward maturity. The findings agree with the findings of Groninger et al. (2000) who examined soil horizonation based on published soil surveys and other off-site data. Results from the current study show that upper soil layer development continues following reforestation and suggests an asymptotic curve arises over longer time periods ( $>20$ years). The construction of mid range and long term trajectory curves remains difficult because a paucity of data exists for restored agricultural wetland areas with intermediate ages between 20 years and maturity; due to the fact that restoration activities within the LMV only began in recent decades (King and Keeland, 1999).

The observed increases in $\mathrm{A}$ and $\mathrm{O}$ horizon development prove measurable using rapid assessment techniques. The accumulation of soil organic matter within near-surface horizons has been linked with wetland hydrology (Reddy and DeLaune, 2008). Results of the current study demonstrate that hydrology within the study area remains driven by both precipitation and backwater flooding resulting from increased river stage (Fig. 3). Further, increased total organic carbon concentrations occurred in areas exhibiting a large number of high water table events (Fig. 3). Findings suggest that soil horizon development represents an appropriate and useful indicator of restoration trajectory and performance within project relevant timescales.

The other two variables of interest, shrub-sapling density and ground vegetation cover, display a different pattern with forest age. The variables increase initially after restoration, followed by a sharp decline 15-20 years post reforestation (Fig. 2). The timing of the change in variable corresponds with the development of tree succession and associated canopy closure approximately $15-20$ years following restoration planting (Fig. 4). Smith and Klimas (2002) predicted that variable responses would follow the observed patterns and display recovery curves of similar shape, although they provide no statistical data. Additionally, other studies report a 20 year canopy closure threshold for planted oak species (Quercus spp.) in the LMV (Twedt and Portwood, 1997; Allen et al., 2001; Williams et al., 1997). Following the closure of the canopy, the onset of ground shading initiates the observed decreases in shrub-sapling density and percent ground vegetation cover via light limitation (Allen, 1997). Results support the application of shrub-sapling density and ground vegetation cover as useful indicators of restoration trajectory and performance in the early years following reforestation. Also, the observed decreases in both variables following tree canopy closure suggest an additional benchmark for intermediate 

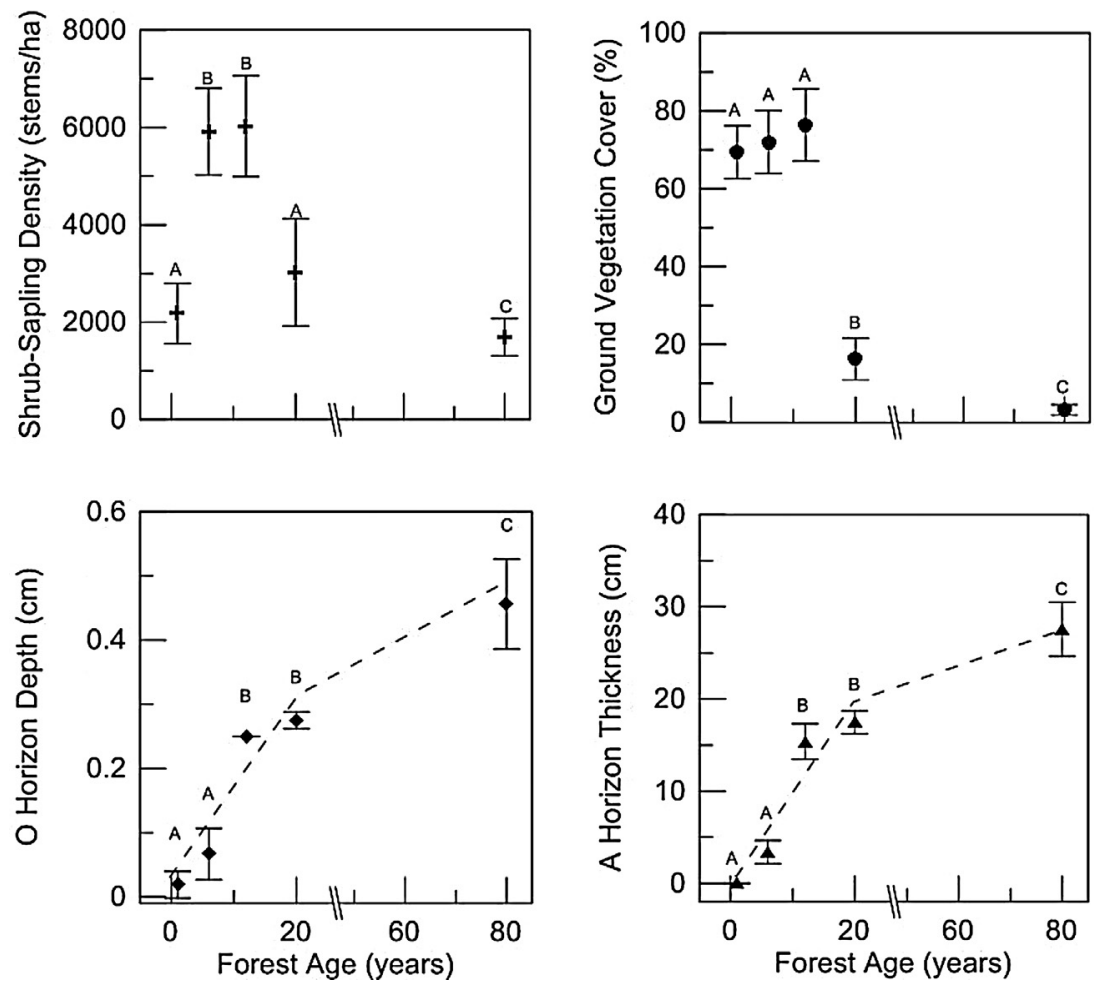

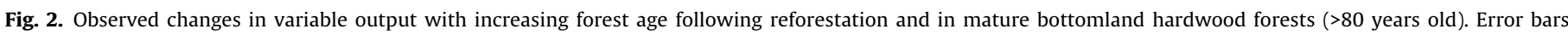

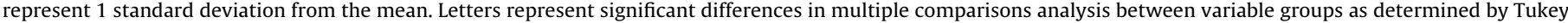
HSD and LSD tests. Note the broken axis between 20 and 40 years. Dashed lines represent the rate of $\mathrm{O}$ and A soil horizonation.

stage (mid-successional) restoration standards following approximately 20 years of restoration as observed in the break in slope within log transformed data (Fig. 4).

The data presented above identifies four rapid assessment variables that respond quickly following restoration plantings. In order to develop early restoration trajectories and performance standards, efforts should focus on variables capable of determining whether a restoration project is on a pathway toward the desired outcome. Results examining sapling and shrub density shows a significant increase during the first 6-7 years following restoration, while the development of soil horizons required $11-12$ years before measurable impacts were observed. Resource managers should incorporate specific, numerical increases in sapling and shrub density as a restoration milestone within mitigation requirements
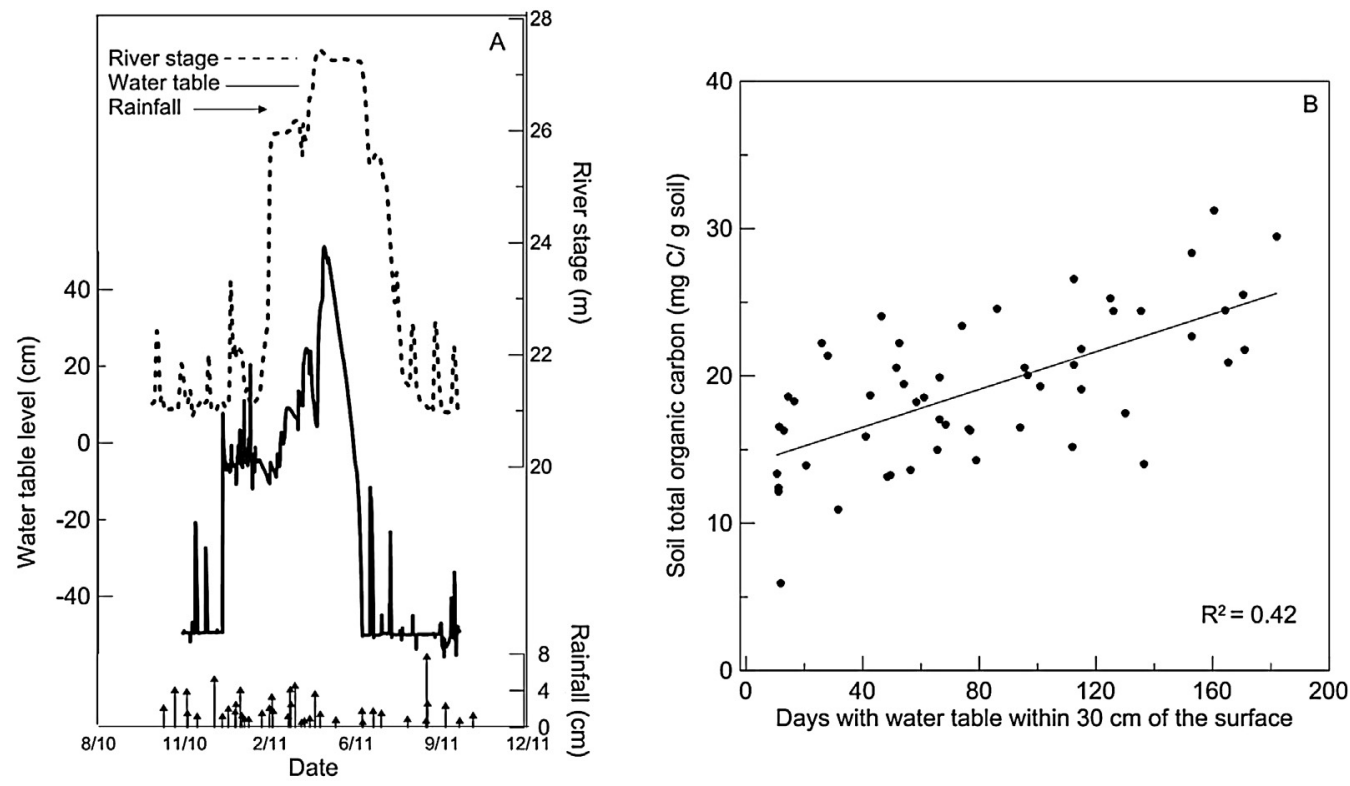

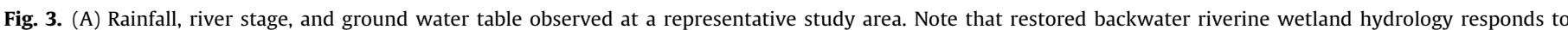

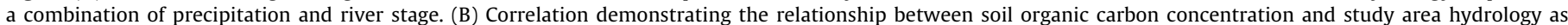

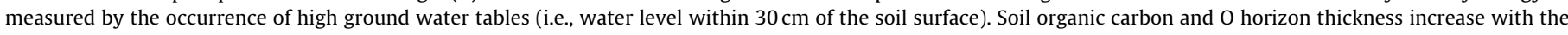
occurrence of high water tables. 

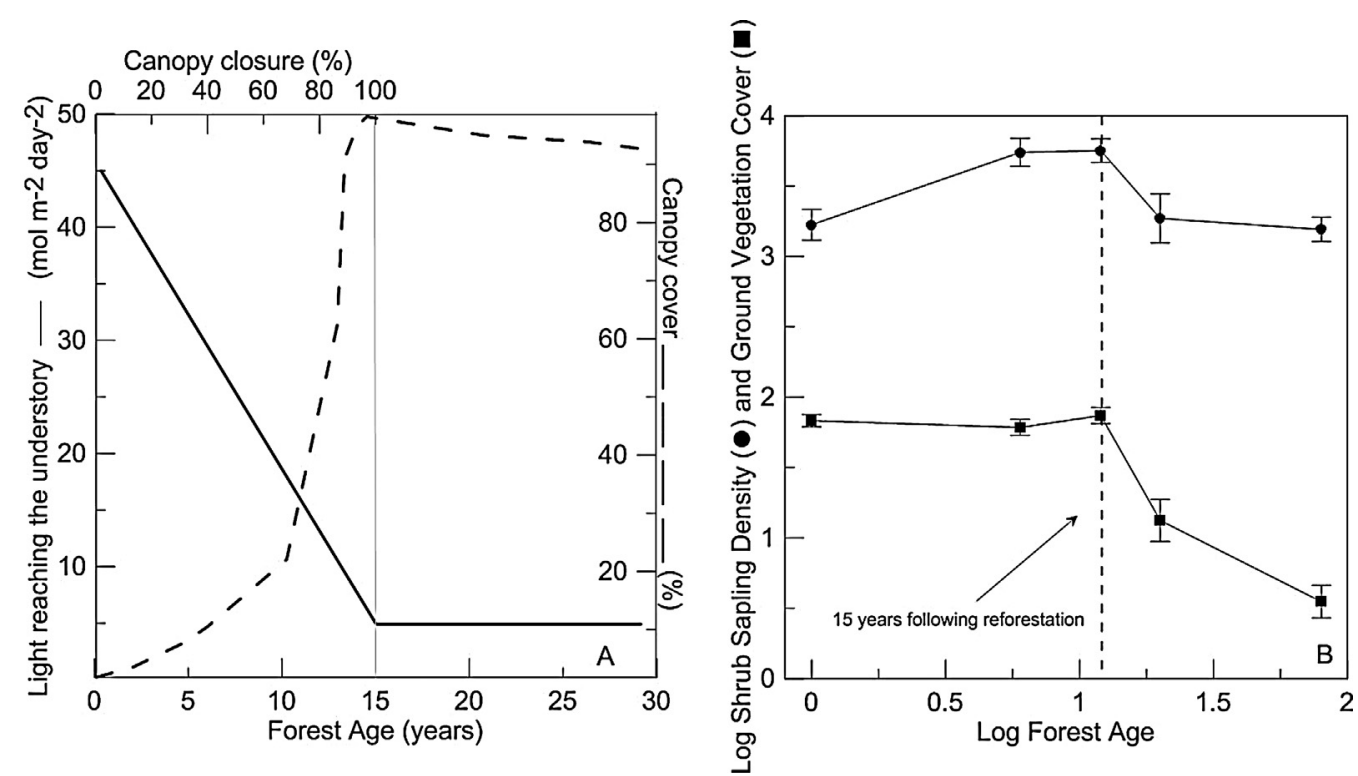

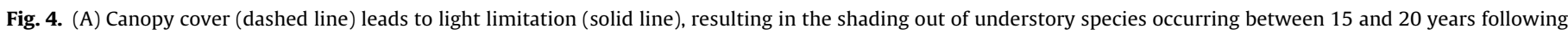

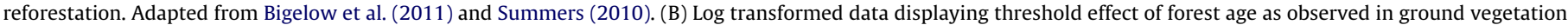
cover and sapling-shrub density data. Note the apex and subsequent decline in occurring at 15 years following reforestation.

in the first years after restoration, followed by soil horizonation milestones in longer-term monitoring requirements. For example, the current study reports that sapling-shrub density should double over 6-7 years of restoration. Developing early performance standards allows restoring entities to take corrective actions if needed (e.g., replanting or additional site modification) within project monitoring timeframes. Restoration performance standards remain unique for different ecosystems and regions, with the reported data applying to agricultural areas within the LMV undergoing bottomland hardwood wetland reforestation.

Thirteen variables evaluated as part of the rapid assessment failed to respond rapidly following forested wetland replanting. However, these variables play an important role in determining overall site condition in both young and mature ecosystems. The variables examined (Table 2 ) classify into three main categories: (1) rapid response variables with a high potential to change in the first years following reforestation, (2) response variables requiring additional time (e.g., >15 years) to display a measureable effect, and (3) stable variables that remain fixed over time. The current study establishes four rapid response variables. Response variables including tree density and basal area increase over time following 20 years of reforestation growth as suggested by Smith and Klimas (2002). On the other hand, stable variables such as flood frequency and the size of the wetland tract are not likely to change within project timescales.

Establishing three variable categories helps determine ecosystem structural and functional responses to reforestation. However the fact that many variables remain essentially constant following restoration requires that managers maximize these variables through appropriate selection of restoration sites. For example, restoring entities should strive to create connected tracts of wetland area, plant appropriate vegetation, and consider both geomorphic position and landscape alterations affecting a given restoration project (Smith et al., 2008).

In situations where project goals include determining ecosystem conditional/functional change over time, resource managers should focus on variables that respond within the timescale of interest. When developing restoration trajectory curves and defining restoration performance milestones, additional emphasis must be placed on the subset of assessment variables that display rapid response and address both practical and ecological concerns. The combination of rapid response, response, and stable assessment variables characterize overall site conditions at longer timescales and all variables should be incorporated into restoration milestones as appropriate.

\section{Conclusions}

Determining the performance of restoration projects remains problematic due to the time required for forested wetlands to reach maturity, limited monitoring requirements, and a lack of coherent performance standards. Identifying measurable rapid assessment variables enables resource managers to establish early restoration milestones that examine the likely trajectory of a reforested area within project relevant timescales. Four rapid assessment variables showed strong correlations within recently reforested agricultural areas. Soil $\mathrm{O}$ and $\mathrm{A}$ horizon increased throughout the restoration chronosequence, providing direct relationships with forest age. Shrub-sapling density and ground vegetation cover increased in young restoration sites, followed by decreasing variable output with the onset of canopy closure, thus providing performance standards in both early and intermediate age forests. Assessment variables showing a rapid response following reforestation define early restoration trajectories and performance, allowing for corrective action within project relevant monitoring periods. When developing restoration trajectory curves and determining restoration performance milestones, emphasis should be placed on a subset of assessment variables that respond quickly and address both practical and ecological concerns. Additionally, variables that respond slowly or remain stable over project timescales should be maximized through site selection and reforestation techniques.

\section{References}

Allen, J.A., Keeland, B.D., Stanturf, J.A., Clewell, A.F., Kennedy Jr., H.E., 2000. A guide to bottomland hardwood restoration. US Forest Service, General Technical Report SRS-40.

Allen, J.A., Keeland, B.D., Stanturf, J.A., Clewell, A.F., Kennedy Jr., H.E., 2001. A guide to bottomland hardwood restoration: U.S. Geological Survey. In: Biological Resources Division Information and Technology Report USGS/BRD/ITR- 
2000-0011. U.S. Department of Agriculture, Forest Service, Southern Research Station, General Technical Report SRS-40.

Allen, J.A., 1997. Reforestation of bottomland hardwoods and the issues of species diversity. Restoration Ecol. 5, 125-134.

Battaglia, L.L., Minchin, P.R., Pritchett, D.W., 2002. Sixteen years of old-field succession and reestablishment of a bottomland hardwood forest in the lower Mississippi Alluvial Valley. Wetlands 22,1-17.

Berkowitz, J.F., Casper, A.F., Noble, C.V., 2010. A multiple watershed field test of hydrogeomorphic functional assessment of headwater streams-variability in field measurements between independent teams. Ecol. Indic. 11 (5), 1472-1475.

Berkowitz, J.F., Sallee, J.B., 2011. Investigating problematic hydric soils using hydrology, IRIS tubes, chemistry, and the hydric soils technical standard. Soil Sci. Soc. Am. J. 75 (6), 2379-2385.

Bigelow, S.W., North, M.P., Salk, C.F., 2011. Using light to predict fuel reduction and group select effects in Sierran mixed conifer forest. Can. J. For. Res. 41, 2051-2063.

Brinson, M.M., 1993. A Hydrogeomorphic Classification for Wetlands. U.S. Army Corps of Engineers, Waterways Experiment Station, Vicksburg, MS, Wetlands Research Program Technical Report WRP-DE-4.

Brinson, M.M., Kruczynski, W., Lee, L.C., Nutter, W.L., Smith, R.D., Whigham, D.F., 1994. Developing an approach for assessing the functions of wetlands. In: Mitsch, W.J. (Ed.), Global Wetlands: Old World and New. Elsevier Science, NY, pp. 615-624.

Brinson, M.M., Rheinhardt, R., 1996. The role of reference wetlands in functional assessment and mitigation. Ecol. Appl. 6, 69-76.

Chorover, J., Kretzschmar, R., Garcia-Pichel, F., Sparks, D., 2007. Surface biogeochemical processes within the critical zone. Elements 3, 321-326.

Clewell, A.F., Lea, R., 1990. Creation and restoration of forested wetland vegetation in the southeastern United States. In: Kusler, J.A., Kentula, M.E. (Eds.), Wetland Creation and Restoration: The Status of the Science. Island Press, Washington, DC, pp. 195-232.

Gardiner, E.S., Stantuft, J.A., Schweitzer, C.J., 2004. An afforestation system for restoring bottomland hardwood forests: biomass accumulation of Nuttall Oak Seedings inplanted beneath Eastern Cottonwood. Restoration Ecol. 12, 525-532.

Gardiner, E.S., Oliver, J.M., 2005. Restoration of bottomland hardwood forests in Lower Mississippi Alluvial Valley U. S. A. In: Stanturf, J.A., Madsen, P. (Eds.), Restoration of Boreal and Temperate Forests. CRC Press, Boca Raton, FL, USA, pp. 235-251.

Groninger, J.W., Aust, W.M., Miwa, M., Stanturf, J.A., 2000. Growth predictions for tree species planted on marginal soybean lands in the Lower Mississippi Valley. J. Soil Water Conserv. 55, 91-95.

Hamel, P.B., 2003. Winter bird community differences among methods of bottomland hardwood forest restoration: results after seven growing seasons. Forestry 76, 197-735.

Harris, J.A., Hobbs, R.J., Higgs, E., Aronson, J., 2006. Ecological restoration and global climate change. Restoration Ecol. 14, 170-176.

Haynes, R.J., Bridges, R.J., Gard, S.W., Wilkins, T.W., Cook Jr., H.R., 1995. Bottonland hardwood reestablishment efforts for the US Fish and Wildlife Service: Southeast Region. In: Fischenich, J.M., Lloyd, C.M., Palmero, M.R. (Eds.), Proceedings of the National Wetlands Engineering Workshop. Technical Report-WRP-RE-8. US Army Corps of Engineers, Waterways Experiment Station, Vicksburg, MS, pp. 322-334.

Hefner, J.M., Brown, J.D., 1995. Wetland trends in the southeastern United States. Wetlands 4, 1-11.

Hobbs, R.J., Cramer, V.A., 2008. Restoration ecology: interventionalist approaches for restoring and maintaining ecosystem function in the face of rapid environmental change. Annu. Rev. Environ. Resour. 33, 39-61.

Hobbs, R.J., Harris, J.A., 2001. Restoration ecology: repairing the Earth's ecosystsmes in the new millennium. Restoration Ecol. 9, 239-246.

Hughes, F.R., Colston, A.C., Mountford, J.O., 2005. Restoring riparian ecosystems: the challenge of accommodating variability and designing restoration trajectories. Ecol. Soc. 10, 1-22.

Humphrey, M.L., Lin, J.P., Kleiss, B.A., Evans, D.E., 2004. Monitoring Wetland Functional Recovery of Bottomland Hardwood Sites in the Yazoo Basin, MS. Tech Note ERDC/EL TN-04-01. US Army Engineer Research and Development Center, Vicksburg, MS.

Jackson, S.T., Hobbs, R.J., 2009. Ecological restoration in the light of ecological history. Science 325, 567-569.

Kentula, M.E., Brooks, R.P., Gwin, S.E., Holland, C.C., Sherman, A.D., 1992. Approach to decision making in wetland restoration and creation. EPA-600/R-92/150, Corvallis, OR.

King, S.L., Keeland, B.D., 1999. Evaluation of reforestation in the lower Mississippi River Alluvial Valley. Restoration Ecol. 7, 348-359.

King, S.L., Twedt, D.L., Wilson, R.R., 2006. The role of the Wetland Reserve Program in conservation efforts in the Mississippi River Alluvial Valley. Wildlife Soc. Bull. 34 (4), 914-920.

Klimas, C.V., Murray, E.O., Langston, H., Pagan, J., Witsell, T., Foti, T., 2004. A Regional Guidebook for Applying the Hydrogeomorphic Approach to Assessing WetlandFunctions of Forested Wetlands in the Delta Region of Arkansas, Lower Mississippi River Alluvial Valley. ERDC/EL TR-04-16. U.S. Army Engineer Research and Development Center, Vicksburg, MS.
Kusler, J.A., 1986. Wetland creation-restoration: a summary of science views and perspectives. In: Kusler, J.A., Quammen, M.L., Brooks, G. (Eds.), Proceedings of the National Wetland Symposium: Mitigation of impacts and losses. ASWM Tech Report. Association of State Wetland Managers, Berne, NY, pp. 400-446.

Landin, M.C., Webb, J.W., 1986. Wetland development and restoration as part of the Corps of Engineers programs. In: Kusler, J.A., Quammen, M.L., Brooks, G. (Eds.) Proceedings of the National Wetland Symposium: Mitigation of impacts and losses. ASWM Tech Report. Association of State Wetland Managers, Berne, NY pp. 388-391.

Mack, J.J., 2007. Developing a wetland IBI with statewide application after multiple testing iterations. Ecol. Indic. 7 (4), 864-881.

National Research Council, 1995. Wetlands: Characteristics and Boundaries. National Academy Press, Washington, DC.

National Weather Service., 2012. National Weather Service Forecast Office, Jackson Mississippi. http://www.nws.noaa.gov/climate/index.php?wfo=jan

The Nature Conservancy, 1992. Restoration of the Mississippi River Alluvial Plain as a Functional Ecosystem. Southeastern Louisiana University, Hammond, LA

Reddy, K.R., DeLaune, R.D., 2008. Biogeochemistry of Wetlands: Science and Applications. CRC Press, Boca Raton, FL.

Ruiz-Jaen, M.C., Aide, T.M., 2005. Restoration success: how is it being measured? Restoration Ecol. 13, 569-577.

Saucier, R.T., 1994. Geomorphology and Quaternary Geologic History of the Lower Mississippi Valley. U. S. Army Engineer Waterways Experiment Station, Vicksburg, MS.

Smith, M.S., Euliss, N.H., Wilcox, D.A., Brinson, M.M., 2008. Application of a geomorphic and temporal perspective to wetland management in North America. Wetlands 28, 563-577.

Smith, R.D., Klimas, C.V., 2002. A Regional Guidebook for Applying the Hydrogeomorphic Approach to Assessing Wetland Functions of Selected Regional Wetland Subclasses, Yazoo Basin, Lower Mississippi River Alluvial Valley. ERDC/EL TR-024. US Army Engineer Research and Development Center, Vicksburg, MS.

Soil Survey Staff. 2011, Natural Resources Conservation Service. United States Department of Agriculture. Web Soil Survey. Available online at http://websoilsurvey.nrcs.usda.gov/. Accessed 09/01/11.

Sparks, D.L., 1996. Methods of Soil Analysis. Part 3: Chemical Methods, 3rd ed. Soil Science Society of America and American Society of Agronomy, Madison, Wisconsin.

Spencer, D.R., Perry, J.E., Silberhorn, G.M., 2001. Early succession in bottomland hardwood forests of southeastern Virginia. Environ. Manag. 27, 559-570.

SPSS, 2011 Version 20 for Windows., 2011. Released 11/01/2011. IBM Inc. Chicago, IL.

Stander, E.K., Ehrenfeld, J.G., 2009. Rapid assessment of urban wetlands: functional assessment model development and evaluation. Wetlands 29 (1), 261-276.

Stanturf, J.A., Gardiner, E.S., 2000. Restoration of bottomland hardwoods in the Lower Mississippi Alluvial Valley. In: Sustaining Forests: The Science of Forest Assessment. Southern Forest Resource Assessment, Durham, NC.

Stein, E.D., Fetscher, A.E., Clark, R.P., Wiskind, A., Grenier, J.L., Sutula, M., Collins J.N., Grosso, C., 2009. Validation of a wetland rapid assessment method: use of EPA's level 1-2-3 framework for method testing and refinement. Wetlands 29 (2), 648-665.

Steyer, G.D., Sasser, C.E., Visser, J.M., Swenson, E.M., Nyman, J.A., Raynie, R.C., 2003. Monitoring system for evaluating wetland restoration trajectories in Louisiana. Environ. Monit. Assess. 81, 107-117.

Summers, E.A., 2010. Evaluating Ecological Restoration in Tennessee Hardwood Bottomland Forests. Masters Thesis. University of Tennessee, Knoxville TN.

Thom, R.M., 1997. System-development matrix for adaptive management of coastal restoration projects. Ecol. Eng. 8, 219-232.

Twedt, D.J., Portwood, J., 1997. Bottomland hardwood reforestation for neotropical migratory birds: are we missing the forest for the trees? Wildlife Soc. Bull. 25 647-653.

U.S. Congress, 1985. The Food Security Act of 1985. Public Law 100-233. US Congress, Washington DC

U.S. Army Corps of Engineers, 1989. Yazoo backwater area mitigation lands, Lake George property land acquisition, Yazoo Basin. In: Mississippi: Environmenta Assessment. US Army Corps of Engineers, Vicksburg District, Vicksburg, Mississippi.

U.S. Army Corps of Engineers, 2005. Technical Standard for Water-Table Monitoring of Potential Wetland Sites. ERDC TN-WRAP-05-02. US Army Engineer Research and Development Center, Vicksburg, MS.

U.S. Army Corps of Engineers. 2012. RiverGages: Water levels of rivers and lakes http://rivergages.mvr.usace.army.mil/WaterControl/new/layout.cfm

Wilkins, S.D., Keith, A., Adams, P., 2003. Measuring success: evaluating the restoration of grassy eucalypt woodland on the Cumberland Plain, Sydney Australia. Restoration Ecol. 11, 489-503.

Williams, H.M., Craft, M.H., Young, G.L., 1997. Reforestation of Frequently Flooded Agricultural Fields: A Compendium of Results from Research Conducted at the Lake George Wetland and Wildlife Restoration Project. Army Engineer Waterways Experiment Station, Mississippi, U. S, Technical report; WRP-RE-18.

Zedler, J.B., 1996. Ecological issues in wetland mitigation: an introduction to the forum. Ecological Appl. 6 (1), 33-37. 